\title{
Antimicrobial susceptibility profile of historical and recent Brazilian pig isolates of Pasteurella multocida ${ }^{\mathbf{1}}$
}

\author{
Amanda F. Amaral ${ }^{*}$ (D), Raquel Rebelatto ${ }^{3}$, Cátia S. Klein ${ }^{3}$, Karine Ludwig Takeuti ${ }^{4}$, \\ João X.O. Filho ${ }^{4}$, Nelson Morés ${ }^{3}$, Marisa R.I. Cardoso ${ }^{5}$ and David E.S.N. Barcellos ${ }^{4}$
}

\begin{abstract}
Amaral A.F., Rebelatto R., Klein C.S., Takeuti K.L., Oliveira Filho J.X., Morés N., Cardoso M.R.I. \& Barcellos D.E.S.N. 2019. Antimicrobial susceptibility profile of historical and recent Brazilian pig isolates of Pasteurella multocida. Pesquisa Veterinária Brasileira 39(2):107-111. Department of Population Health and Pathobiology, College of Veterinary Medicine, North Caroline State University, 1060 William Moore Drive, Raleigh, NC 27607, USA.E-mail: afamaral@ncsu.edu

Pasteurella (P.) multocida is the causative agent of pneumonic pasteurellosis in swine, which is commonly associated with the final stages of enzootic pneumonia or porcine respiratory disease complex. Although this syndrome is one of the most common and important diseases of pigs, data on antimicrobial susceptibility of $P$. multocida isolates are uncommon in Brazil. Therefore, the present study was carried out to determine and to compare antimicrobial susceptibility profile of Brazilian P. multocida isolated from pigs with lesions of pneumonia or pleuritis during two-time periods. Historical isolates (period of 1981 to 1997; $=44$ ) and recent isolates (period of 2011 to 2012; $n=50$ ) were used to determine the MIC of amoxicillin, enrofloxacin, florfenicol and tetracycline by microbroth dilution. Florfenicol had the lowest level of resistance for both historical and recent isolates ( $0 \%$ and $6 \%$, respectively), while tetracycline had the highest $(20.5 \%$ and $34 \%$, respectively). Multi-drug resistance (MDR) to amoxicillin/florfenicol/tetracycline was observed in $6 \%$ of recent isolates. There was a significant increase $(\mathrm{p}<0.05)$ in resistance for amoxicillin and enrofloxacin in recent isolates compared with historic isolates $(3.8 \%$ and $18 \%$, respectively), most likely due to the selective pressure of antimicrobial usage to treat and prevent $P$. multocida infections. The results of this study showed an increase of isolates resistant to important drugs used in treatment of $P$. multocida infections in pigs, demonstrating the need for the implementation of rational use of antimicrobials in Brazilian swine industry.
\end{abstract}

INDEX TERMS: Antimicrobial susceptibility, Brazilian pig, Pasteurella multocida, minimum inhibitory concentration (MIC), microbroth dilution, resistance, swine, pigs, bacterioses.

\footnotetext{
${ }^{1}$ Received on September 3, 2018.

Accepted for publication on September 12, 2018.

${ }^{2}$ Department of Population Health and Pathobiology, College of Veterinary Medicine, North Carolina State University (NCSU), 1060 William Moore Drive, Raleigh, NC 27607, USA. *Corresponding author: afamaral@ncsu.edu

${ }^{3}$ Embrapa Suínos e Aves, Sanidade Animal, Rodovia BR-153 Km 110, Distrito de Tamanduá, Concórdia, SC 89700-991, Brazil. E-mails: raquel.rebelatto@embrapa.br, catia.klein@embrapa.br,nelson.mores@embrapa.br

${ }^{4}$ Setor de Suínos, Faculdade de Veterinária, Universidade Federal do Rio Grande do Sul (UFRGS), Av. Bento Gonçalves 9090, Porto Alegre, RS 91540-000, Brazil. E-mails: karinelt87@yahoo.com.br, davidbarcellos@terra.com.br, joaoxvet@gmail.com

${ }^{5}$ Setor de Medicina Veterinária Preventiva, Faculdade de Veterinária, Universidade Federal do Rio Grande do Sul (UFRGS), Av. Bento Gonçalves 9090, Porto Alegre, RS 91540-000. E-mail: mcardoso@ufrgs.br
}

RESUMO.- [Perfil de suscetibilidade a antimicrobianos de isolados históricos e contemporâneos de Pasteurella multocida de suínos no Brasil.] Pasteurella (P.) multocida é o agente da pasteurelose pneumônica em suínos, a qual é comumente associada com o estágio final da pneumonia enzoótica suína ou complexo das doenças respiratórias dos suínos. Apesar de ser uma das doenças mais comuns e importantes na suinocultura, dados sobre suscetibilidade antimicrobiana de isolados de $P$. multocida são raros no Brasil. Dessa forma, o presente estudo foi realizado para determinar e comparar o perfil de suscetibilidade de isolados de $P$. multocida de suínos com lesões de pneumonia ou pleurite no Brasil durante dois períodos. Isolados históricos 
(período de 1981 a 1997; n=44) e contemporâneos (período de 2011 a 2012; $n=50$ ) foram usados para determinar a concentração inibitória mínima (CIM) de amoxicilina, enrofloxacina, florfenicol e tetraciclina através do teste de microdiluição em caldo. Florfenicol apresentou o menor nível de resistência para ambos os isolados históricos e contemporâneos (0\% e 6\%, respectivamente), enquanto que tetraciclina apresentou o maior nível de resistência (20.5\% e $34 \%$, respectivamente). Resistência a múltiplos antimicrobianos (amoxicilina, florfenicol e tetraciclina) foi observada em $6 \%$ dos isolados recentes. Foi observado aumento significativo $(\mathrm{p}<0.05)$ na resistência a amoxicilina e enrofloxacina em isolados recentes comparado com isolados históricos (3.8\% e 18\%, respectivamente), provavelmente devido à pressão de seleção de antimicrobianos usados no tratamento e prevenção de infecções causadas por P. multocida. Os resultados deste trabalho demostraram o aumento de isolados resistentes a importantes drogas utilizadas no tratamento de infecções causadas por P. multocida em suínos, evidenciando a necessidade da implementação do uso racional de antimicrobianos na suinocultura brasileira.

TERMOS DE INDEXAÇ̃̃O: Antimicrobianos, Pasteurella multocida, concentração inibitória mínima (CIM), microdiluição em caldo, resistência, suínos, bacterioses.

\section{INTRODUCTION}

Pasteurella (P.) multocida is the causative agent of pneumonic pasteurellosis in swine. It is commonly associated with the final stages of enzootic pneumonia or porcine respiratory disease complex (Register et al. 2012), wich is one of the most frequent and costly disease of pigs, since it has a negative impact on weigth gain and feed conversion (Noyes et al. 1990, Pijoan 2006).

Antimicrobials are still the first choice for prevention and control of P. multocida infections in swine. However, the use of antimicrobial agents can lead to increase of resistance (Schwarz et al. 2001). Monitoring antimicrobial susceptibility from $P$. multocida isolated from pigs over time provides valuable information about changes, which may be occurring in susceptibility patterns and is an important tool in effective antimicrobial therapy (Schwarz \& Chaslus-Dancla 2001). Besides that, these data can serve as a decision guidance to choose the drug therapy and may help to recognize the emergence of new resistance phenotypes.

Amoxicillin, enrofloxacin, florfenicol and tetracycline are commonly used in Brazilian swine herds to prevent or to treat respiratory diseases, but data on antimicrobial susceptibility of P. multocida isolates are scant (Stepan et al. 1998, Borowski et al. 2002, Heres 2009, Mores et al. 2015). Moreover, to the best of our knowledge, there is no information on antimicrobial resistance profiles over time and only one study (Mores et al. 2015) about minimal inhibitory concentration (MIC) of P. multocida isolated in Brazil.

Therefore, this study was carried out to determine and to compare antimicrobial susceptibility profiles during two-time periods by determining the MIC of selected antimicrobial agents for a panel of $P$. multocida strains isolated from pigs with lesions of pneumonia or pleuritis in Brazil.

\section{MATERIALS AND METHODS}

A total of 94 Pasteurella multocida isolated from pig lesions of pneumonia or pleuritis in Brazil were tested. These isolates belonged to two groups: 1) historical isolates, wich comprised 44 isolates collected in the state of Rio Grande do Sul, Brazil, from 1981 to 1997; 2 ) recent isolates, wich included 50 isolates collected in six states of Brazil: Minas Gerais (21 isolates), Rio Grande do Sul (14 isolates), São Paulo (6 isolates), Santa Catarina (4 isolates), Mato Grosso (4 isolates) and Paraná (1 isolate) from 2011 to 2012. Historical isolates were preserved lyophilized and stored at $4-8^{\circ} \mathrm{C}$, while recent isolates were preserved and stored in brain heart infusion (BHI) broth $\left(\mathrm{Oxoid}^{\circledR}\right.$, Cambridge, UK) containing $50 \%$ sheep blood at $-70^{\circ} \mathrm{C}$. Reactivation and preliminary tests for the confirmation of pure cultures of $P$. multocida were performed according to Markey et al. (2013) and Townsend et al. (2001) by microbiology and molecular assay, respectively.

MIC testing was performed by microbroth dilution method in accordance with criteria provided in the Clinical Laboratory Standards documents VET01-A4 (CLSI, 2013a) and VET-S2 (CLSI, 2013b). Isolates were tested against four antimicrobials at the listed dilutions: amoxicillin $(0.0625-512 \mu \mathrm{g} / \mathrm{mL})$, enrofloxacin $(0.00098-64 \mu \mathrm{g} / \mathrm{mL})$, florfenicol $(0.125-32 \mu \mathrm{g} / \mathrm{mL})$ and tetracycline $(0.0625-16 \mu \mathrm{g} / \mathrm{mL})$. Staphylococcus aureus (ATCC 29213) was used as reference strain for quality control. Prior to MIC testing, bacterial isolates were cultured on blood agar base (Oxoid ${ }^{\circledR}$ ) supplemented with $5 \%$ sheep blood and incubated for $18-24 \mathrm{~h}$ at $37^{\circ} \mathrm{C}$. Each isolate was suspended in saline to obtain the $0.5 \mathrm{McF}$ arland turbidity. From this suspention, $100 \mu \mathrm{L}$ was added to $9,900 \mu \mathrm{L}$ of Cation-adjusted Mueller-Hinton broth for plate inoculation. Inoculated plates were incubated for $24 \mathrm{~h}$ at $35^{\circ} \mathrm{C}$. The MIC for each isolate was determined as the lowest concentration of antimicrobial that prevented visible growth. All isolates were tested in triplicate. At least two out of three results had to be the same, if not, MIC testing was repeated. MICs were summarized and reported as susceptible (S), intermediate (I) and resistant (R) according to CLSI veterinary breakpoints (CLSI $2013 \mathrm{~b}$ ). This applies for the following antimicrobials (expressed as $\mu \mathrm{g} / \mathrm{mL}$ in parentheses): amoxicillin ( $\mathrm{S} \leq 0.5, \mathrm{I}=1, \mathrm{R} \geq 2)$, enrofloxacin $(\mathrm{S} \leq 0.25, \mathrm{I}=0.5, \mathrm{R} \geq 1)$, florfenicol $(\mathrm{S} \leq 2, \mathrm{I}=4, \mathrm{R} \geq 8)$ and tetracycline $(\mathrm{S} \leq 0.5, \mathrm{I}=1, \mathrm{R} \geq 2)$. As described in CLSI, ampicillin standards were used for interpreting data of amoxicillin.

Data were described considering values of MIC maximum, MIC minimum, MIC 50, MIC 90 and susceptibility profiles by groups of strains (historical or recent isolates). A non-parametric analysis was used to compare MIC values and susceptibility profiles between groups of strains and differences were determined using Fisher's exact test (SAS, Version 9.4, 2012). Results were considered statistically significant if $\mathrm{p} \leq 0.05$.

\section{RESULTS}

The MICs of reference strain in each test run were within the CLSI acceptable quality control ranges. In the present study, MIC range of amoxicillin for Staphylococcus aureus ATCC 29213 was $1-4 \mu \mathrm{g} / \mathrm{mL}$. The MIC distribution, MIC range, MIC 50, MIC 90 and antimicrobial resistance profile of four antimicrobial for 94 isolates of Pasteurella multocida are summarized in Tables 1,2 and 3.

Recent isolates had higher numeric MIC ranges than historical isolates for all antimicrobial tested. MIC 90 was also higher in recent isolates, except for tetracycline, that presented the same MIC $90(4 \mu \mathrm{g} / \mathrm{mL})$. Florfenicol had the 
Table 1. Percentage distribution (\%) according to the minimum inhibitory concentration (MIC) of four antimicrobials for 44 historical (H) and 50 recent (R) Pasteurella multocida isolates

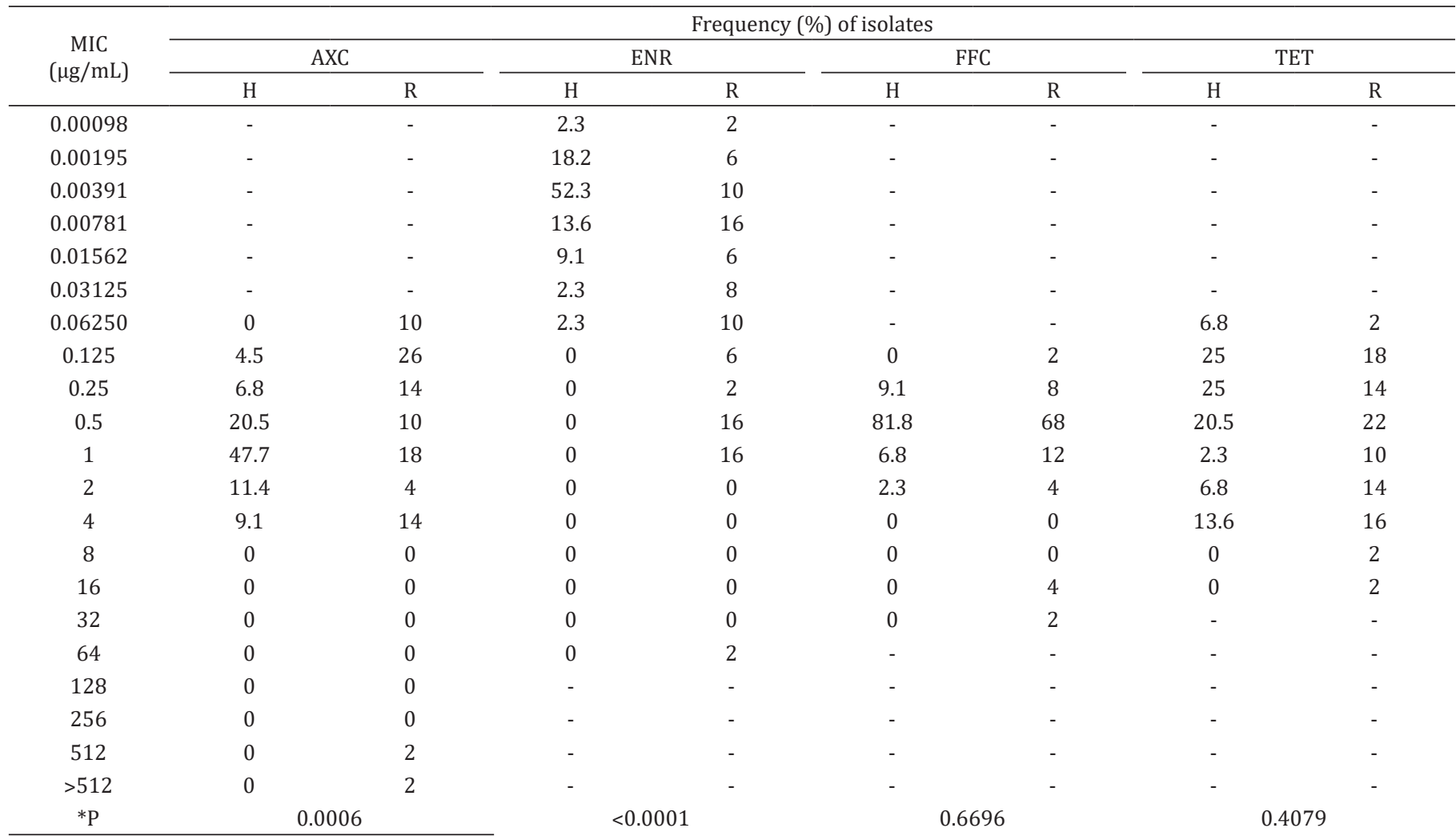

$\mathrm{AXC}=$ amoxicillin, $\mathrm{ENR}=$ enrofloxacin, $\mathrm{FFC}=$ florfenicol, $\mathrm{TET}=$ tetracycline; ${ }^{*} \mathrm{P}=$ Fisher's exact test descriptive level; differences were considered statistically significant when $\mathrm{P} \leq 0.05$; - not tested at this antimicrobial concentration.

Table 2. Minimum inhibitory concentration (MIC) range, MIC 50 and MIC 90 of four antimicrobials for 44 historical (H) and 50 recent (R) Pasteurella multocida isolates

\begin{tabular}{|c|c|c|c|c|c|c|c|c|}
\hline & \multicolumn{8}{|c|}{ MIC $(\mu \mathrm{g} / \mathrm{mL})$ of isolates } \\
\hline & \multicolumn{2}{|c|}{ AMX } & \multicolumn{2}{|c|}{ ENR } & \multicolumn{2}{|c|}{$\mathrm{FFC}$} & \multicolumn{2}{|c|}{ TET } \\
\hline MIC minimum & 0.125 & 0.0625 & 0.00098 & 0.00098 & 0.25 & 0.125 & 0.0625 & 0.0625 \\
\hline MIC 50 & 1 & 0.25 & 0.00391 & 0.0625 & 0.5 & 0.5 & 0.25 & 0.5 \\
\hline MIC 90 & 2 & 4 & 0.01562 & 1 & 0.5 & 1 & 4 & 4 \\
\hline
\end{tabular}

AXC = amoxicillin, ENR = enrofloxacin, FFC = florfenicol, TET = tetracycline; MIC 50, MIC 90 = lowest concentration of antimicrobial agent capable of inhibiting the growth of $50 \%$ and $90 \%$ of isolates, respectively.

Table 3. Antimicrobial susceptibility profile of four antimicrobials for 44 historical (H) and 50 recent (R) Pasteurella multocida isolates

\begin{tabular}{|c|c|c|c|c|c|c|c|c|}
\hline \multirow{3}{*}{ Susceptibility profile } & \multicolumn{8}{|c|}{ Frequency (\%) of isolates } \\
\hline & \multicolumn{2}{|c|}{ AMX } & \multicolumn{2}{|c|}{ ENR } & \multicolumn{2}{|c|}{ FFC } & \multicolumn{2}{|c|}{ TET } \\
\hline & $\mathrm{H}$ & $\mathrm{R}$ & $\mathrm{H}$ & $\mathrm{R}$ & $\mathrm{H}$ & $\mathrm{R}$ & $\mathrm{H}$ & $\mathrm{R}$ \\
\hline Resistant & 18.2 & 22 & 0 & 18 & 0 & 6 & 20.5 & 34 \\
\hline Susceptible & 34.1 & 60 & 100 & 66 & 100 & 94 & 77.3 & 56 \\
\hline$* \mathrm{P}$ & \multicolumn{2}{|c|}{0.0080} & \multicolumn{2}{|c|}{$<0.0001$} & \multicolumn{2}{|c|}{0.2450} & \multicolumn{2}{|c|}{0.0735} \\
\hline
\end{tabular}

AXC = amoxicillin, $\mathrm{ENR}=$ enrofloxacin, $\mathrm{FFC}=$ florfenicol, $\mathrm{TET}=$ tetracycline; ${ }^{*} \mathrm{P}=$ Fisher's exact test descriptive level; differences were considered statistically significant when $\mathrm{P} \leq 0.05$. Based on CLSI (2013b) standards. 
lowest level of resistance for both historical and recent isolates ( $0 \%$ and $6 \%$, respectively), while tetracycline had the highest (20.5\% and $34 \%$, respectively).

In historical isolates, $4.5 \%$ of the isolates showed simultaneous resistance to amoxicillin and tetracycline, while in recent isolates $16 \%$ of the isolates showed simultaneous resistance to amoxicillin/tetracycline (4\%), amoxicillin/enrofloxacin (4\%), and enrofloxacin/tetracycline (8\%). Multi-drug resistance (MDR) to amoxicillin/florfenicol/tetracycline was observed in $6 \%$ of recent isolates, while no historical isolates presented MDR.

Susceptibility profiles of historical and recent $P$. multocida isolates were significantly different $(\mathrm{p}<0.05)$ only for amoxicillin and enrofloxacin, wich had an increase in the resistance of $3.8 \%$ and $18 \%$ in recent isolates respectively.

\section{DISCUSSION}

In Brazil, the use of antimicrobial to treat respiratory diseases is a common practice and can be reflecting in the increase of antimicrobial resistance observed overtime. Amoxicillin has been used in Brazil since 1995 and is the most commonly antimicrobial used via feed or water as a herd medication for prophylaxis of pulmonary swine pasteurellosis. Since the exposure of a bacteria to antimicrobial agents can lead to increase of resistance (Bywater 2004), the frequent use of amoxicillin may reflect on the antimicrobial susceptibility profile of Pasteurella multocida, as it was observed in our work an increase in level of resistance (18.2\% historical vs. 22\% recent isolates) and MIC90 ( $2 \mu \mathrm{g} / \mathrm{mL}$ historical vs. $4 \mu \mathrm{g} / \mathrm{mL}$ recent isolates). This result is consistent with the findings of another study that investigated the susceptible level of P. multocida isolates from pigs in the main swine production areas in Brazil. In that study, Mores et al. (2015) found the resistance level to amoxicillin to be $20 \%$. On the contrary, Jong et al. (2014) observed a much lower level of resistance and MIC90 (1.3\% and $0.25 \mu \mathrm{g} / \mathrm{mL}$ respectively) in isolates collected in 11 European countries during 2002-2006.

Enrofloxacin was introduced to pig use in Brazil in 1988 and is widely used to treat pulmonary pasteurellosis. Once more, the selective pressure of the antimicrobial may explain the increase in level of resistance $0 \%$ historical vs. $18 \%$ recent isolates) and MIC90 (0.01562 vs. $1 \mu \mathrm{g} / \mathrm{mL}$ ) observed in the present study. Different from our study, Nedbalcová \& Kučerová (2013) found lower level of resistance and MIC90 of enrofloxacin (1.5\%; $\leq 0.12 \mu \mathrm{g} / \mathrm{mL}$, respectively) in the Czech Republic. The same author performed a further study (Nedbalcová et al. 2014 ) to observe the relationship between antimicrobial resistance and its sales. It was observed a logical link among consumptions and resistance patterns. Nevertheless, overall national sales data have limitations as they do not express real exposure of the animals to antimicrobials.

Florfenicol was introduced in Brazilian pig industry in 1999. In this study, this drug had the lowest level of resistance for both historical and recent isolates ( $0 \%$ and $6 \%$, respectively) and a low MIC90 $(0.5 \mu \mathrm{g} / \mathrm{mL}$ and $1 \mu \mathrm{g} / \mathrm{mL}$ respectively). This may indicate a high efficiency of the drug and/or a difficulty to develop resistance to it. Similar results were found elsewhere, such as a much larger study conducted in North America (United States and Canada) with 2.389 Pasteurella multocida isolates collected during 2001-2010 (Portis et al. 2013) in wich the level of florfenicol resistance was lower than $1 \%$, while the MIC90 was $0.5 \mu \mathrm{g} / \mathrm{mL}$. Another study in Korea also showed a high activity of florfenicol (Shin et al. 2005). In that study, all isolates were susceptible and had a MIC ranging from 0.25 to $0.5 \mu \mathrm{g} / \mathrm{mL}$, and MIC $90 \leq 0.5 \mu \mathrm{g} / \mathrm{mL}$. According to the authors, despite florfenicol has been licensed in Korea for treatment of porcine respiratory infections in 1999 , it has not been previously used.

Despite tetracycline therapeutics had a long story of use in Brazil (since 1960), its use has been decreasing since the 90's because of high levels of resistance in Brazilian pig isolates of Pasteurella multocida (Stepan et al. 1998). More recently, the use has been influenced by the need to comply with export requirements of some of Brazilian pork importers requiring the ban of its use. Furthermore, since tetracycline resistance is widespread (Karriker et al. 2012) and its genes can be located in plasmid (Kehrenberg et al. 2001), resistant strains may still be present in the P. multocida population. This could explain the fact that no significant difference $(p>0.05)$ was found in susceptibility profiles between strains isolated in different periods, with MIC 90 of $4 \mu \mathrm{g} / \mathrm{mL}$ in both historical and recent isolates. In Australia, a similar level of resistance and MIC90 (28\%; $2 \mu \mathrm{g} / \mathrm{mL}$, respectively) against tetracycline were reported in isolates collected from 2002 to 2013 (Dayao et al. 2014).

In the present study, MDR was defined as resistance to three or more antimicrobial classes and $6 \%$ of recent isolates showed MDR. Pasteurella multocida isolates from pigs in Austria from 2002 to 2013 also showed MDR in 4.8\% of their isolates (Dayao et al. 2014). On the other hand, our results showed that none of the historical samples presented MRD, demonstrating once more that exposure to antimicrobial agents over time can lead to increase of bacteria resistance and MDR.

Since the development of new antimicrobial agents is very expensive and time consuming, every effort must be undertaken to retain the efficacy of substances currently available for veterinary use (Boerlin \& White 2013). Furthermore, it is not possible to stop resistance development, but it is possible to slow down the selection and spread of resistance (Schwarz \& Chaslus-Dancla 2001). This underlines the importance of responsible use of antimicrobials when treating P. multocida infections and the need to create national monitoring programs as those already present in other countries like Germany (GERM-Vet), France (Résapath), Czech Republic (Control of Veterinary Biologicals and Medicaments - ISCVBM) and Europe (VetPath) to investigate quantitatively the in vitro susceptibility and assist veterinarians in the selection of the most suitable antibiotic and its correct dose.

\section{CONCLUSION}

Based on the MIC breakpoints obtained there was an increase of resistance in recent isolates for all antimicrobial tested, indicating an increase of resistance over time, most likely caused by the selective pressure of antimicrobial usage to treat and prevent Pasteurella multocida infections in pig farms.

Acknowledgements.- This study was partially supported by funds from Capes. The authors would like to thank Arlei Coldebella (Embrapa Suínos e Aves) for assistance with the statistical analysis, Eliana Dantas (Bayer) and César Feronato (MSD) for the financial support.

Conflict of interest statement.- The authors have no competing interest. 


\section{REFERENCES}

Boerlin P. \& White D.G. 2013. Antimicrobial resistance and its epidemiology, p.21-40. In: Giguère S., Prescott J.F. \& Dowling P.M. (Eds), Antimicrobial Therapy in Veterinary Medicine. 5th ed. Wiley-Blackwell, Ames, Iowa. <http://dx.doi.org/10.1002/9781118675014.ch3>.

Borowski S.M., Barcellos D.E.S.N., Razia L.E. \& Coutinho T.A. 2002. Padrão de resistência antimicrobiana de amostras de Pasteurella multocida isoladas em pulmões de suínos. Revta FZVA Uruguaiana 9:104-110.

Bywater R.J. 2004. Veterinary use of antimicrobials and emergence of resistance in zoonotic and sentinel bacteria in the EU. J. Vet. Med. B. Infect. Dis. Vet. Publ. Health 51(8/9):361-363. <http://dx.doi.org/10.1111/j.1439-0450.2004.00791. x $><$ PMid:15525366>

CLSI 2013a. Performance standards for antimicrobial disck and dilution susceptibility tests for bacteria isolated from animals. Appoved Standard Fourth Edition, CLSI document VET01-A4, Clinical and Laboratory Standards Institute, Wayne, PA.

CLSI 2013b. Performance standards for antimicrobial disck and dilution susceptibility tests for bacteria isolated from animals; Second informational supplement. CLSI document VET01-S2, Clinical and Laboratory Standards Institute, Wayne, PA.

Dayao D.A.E., Gibson J.S., Blackall P.J. \& Turni C. 2014. Antimicrobial resistance in bacteria associated with porcine respiratory disease in Australia. Vet. Microbiol.171(1/2):232-235. <http://dx.doi.org/10.1016/j. vetmic.2014.03.014><PMid:24726505>

Heres T.S. 2009. Caracterização de amostras de Pasteurella multocida isoladas de lesões pneumônicas associadas ou não com circovirose em suínos. Master's in Veterinary Science, Faculdade de Ciências Veterinárias, Universidade Federal do Rio Grande do Sul, Porto Alegre. 64p.

Jong A., Thomas V., Simjee S., Moyaert H., Garch F., Maher K., Morrissey I., Butty P., Klein U., Marion H., Rigaut D. \& Vallé M. 2014. Antimicrobial susceptibility monitoring of respiratory tract pathogens isolated from diseased cattle and pigs across Europe: the VetPath study. Vet. Microbiol. 172(1/2):202-215. <http://dx.doi.org/10.1016/j.vetmic.2014.04.008> <PMid:24837878>

Karriker L.A., Coetzee J., Friendship R.M. \& Prescott J.F. 2012. Drug pharmacology, therapy, and prophylaxis, p.106-118. In: Zimmerman J.J., Karriker L.A., Ramirez A., Schwartz K.J. \& Stevenson G.W. (Eds), Diseases of Swine. 10th ed. Wiley-Blackwell, Ames, Iowa.

Kehrenberg C., Salmon S.A., Watts J.L. \& Schwarz S. 2001. Tetracycline resistance genes in isolates of Pasteurella multocida, Mannheimia haemolytica, Mannheimia glucosidal and Mannheimia varigena from bovine and swine respiratory disease: intergeneric spread of the tet $(\mathrm{H})$ plasmid pMHT1. J. Antimicrob. Chemother. 48(5):631-640. <http://dx.doi.org/10.1093/ jac/48.5.631><PMid:11679552>

Markey B., Leonard F., Archambault M., Culliname A. \& Maguire D. 2013. Pasteurella, Mannheimia, Bibersteinia and Avibacterium species, p.307-
316. In: Markey B., Leonard F., Archambault M., Cullinane A. \& Maguire D. (Eds), Clinical Veterinary Microbiology. 2nd ed. Elsevier, Toronto, Ontario.

Mores M.A.Z., Oliveira Filho J.X., Rebelatto R., Klein C., Barcellos D.E.N., Coldebella A. \& Mores N. 2015. Aspectos patológicos e microbiológicos das doenças respiratórias em suínos de terminação no Brasil. Pesq. Vet. Bras. 35(8):725-733. <http://dx.doi.org/10.1590/S0100-736X2015000800004>

Nedbalcová K. \& Kučerová Z. 2013. Antimicrobial susceptibility of Pasteurella multocida and Haemophilus parasuis isolates associated with porcine pneumonia. Acta Vet. Brno 82(1):3-7. <http://dx.doi.org/10.2754/ avb201382010003>

Nedbalcová K., Nechvatalova K., Pokludova L., Bures J., Kucerova Z., Koutecka L. \& Hera A. 2014. Resistance to selected beta-lactam antibiotics. Vet. Microbiol. 171(3/4):328-336. <http://dx.doi.org/10.1016/j.vetmic.2014.02.004> $<$ PMid:24612952>

Noyes E.P., Feeney D. \& Pijoan C. 1990. Comparison of the effect of pneumonia detected during a lifetime with pneumonia detected at slaughter on growth in swine. J. Am. Vet. Med. Assoc. 197(8):1025-1029. <PMid:2243034>

Pijoan C. 2006. Pneumonic Pasteurellosis, p.719-726. In: Straw B.E., Zimmerman J.J., D’Allaire S. \& Taylor D.J. (Eds), Disease of Swine. 9th ed. State University Press, Ames, Iowa.

Portis E., Linderman C., Johansen L. \& Stoltmann G. 2013. Antimicrobial susceptibility of porcine Pasteurella multocida, Streptococcus suis, and Actinobacillus pleuropneumoniae from the United States and Canada, 2001 to 2010. J. Swine Health Prod. 21:30-41.

Register K.B., Brockmeier S.L. \& Jong C. 2012. Pasteurellosis, p.798-810. In: Zimmerman J.J., Karriker L.A., Ramirez A, Schwartz K.J. \& Stevenson G.W. (Eds), Diseases of Swine. 10th ed. Wiley-Blackwell, Ames, Iowa.

Schwarz S. \& Chaslus-Dancla E. 2001. Use of antimicrobials in veterinary medicine and mechanisms of resistance. Vet. Res. 32(3/4):201-225. <http:// dx.doi.org/10.1051/vetres:2001120><PMid:11432414>

Schwarz S., Kehrenberg C. \& Walsh T.R. 2001. Use of antimicrobial agents in veterinary medicine and food animal production. Int. J. Antimicrob. Agents 17(6):431-437. <http://dx.doi.org/10.1016/S0924-8579(01)00297-7> $<$ PMid:11397611>

Shin S.J., Kang S.G., Nabin R., Kang M.L. \& Yoo H.S. 2005. Evaluation of the antimicrobial activity of florfenicol against bacteria isolated from bovine and porcine respiratory disease. Vet. Microbiol. 106(1/2):73-77.<http:// dx.doi.org/10.1016/j.vetmic.2004.11.015><PMid:15737475>

Stepan A.L., Barcellos D.E.S.N. \& Borowski S.M. 1998. Sensibilidade a antimicrobianos de amostras de Pasteurella multocida isoladas de casos de pleurite em suínos. Pesq. Agropec. Gaúcha 4:19-22.

Townsend K.M., Boyce J.D., Chung J.Y., Frost A.J. \& Adler B. 2001. Genetic organization of Pasteurella multocida cap Loci and development of a multiplex capsular PCR typing system. J. Clin. Microbiol. 39(3):924-929. <http://dx.doi.org/10.1128/JCM.39.3.924-929.2001><PMid:11230405> 